\title{
APLIKASI TEKNIK LOT SIZING PADA PROYEK GEDUNG LABORATORIUM KEBENCANAAN UNIVERSITAS SYIAH KUALA
}

\author{
Erwin Lingga $^{1)}$, Mubarak ${ }^{2)}$, Cut Zukhrina Oktaviani ${ }^{3)}$ \\ ${ }^{1,2,3)}$ Magister Teknik Sipil, Universitas Syiah Kuala \\ Jl. Teuku Nyak Arief, Kopelma, Darussalam, Banda Aceh \\ Email: erwinlingga1980@gmail.com ${ }^{1)}{ }_{\text {mubarak@unsyiah.ac.id }}{ }^{2)}$ \\ cut.zukhrina@unsyiah.ac.id ${ }^{3)}$ \\ Corresponding Author: erwinlingga1980@gmail.com
}

DOI: http://dx.doi.org/10.29103/tj.v11i2.563

(Received: July 2021 / Revised: August 2021 / Accepted: September 2021)

\begin{abstract}
Abstrak
Salah satu faktor mempengaruhi kelancaran dalam pelaksanaan suatu proyek konstruksi adalah pengadaan material ke lokasi. Keterlambatan datangnya material konstruksi yang menyebabkan stockout persediaan material saat akan digunakan membuat pekerjaan menjadi tertunda. Hal ini secara tidak langsung dapat mempengaruhi total waktu pelaksanaan serta biaya proyek. Penentuan tingkat persediaan yang tepat dapat diaplikasikan dengan mengunakan metode Material Requirement Planning (MRP). Tujuan dari penelitian adalah untuk mengetahui ukuran pemesanan dan biaya pengadaan material yang paling efisien dari dua teknik lotsizing yaitu teknik Period Order Quantity (POQ) dan teknik Economic Order Quantity (EOQ) pada Gedung Laboratorium Kebencanaan Universitas Syiah Kuala (USK) di Kota Banda Aceh. Proses yang terdapat dalam MRP meliputi netting, lotting, offsetting, dan explosion. Metode MRP diterapkan pada proyek Gedung Laboratorium Kebencanaan USK, dengan menghitung jumlah kebutuhan material berdasarkan data Rencana Anggaran Biaya (RAB), Analisis Harga Satuan (AHS), dan jadwal pelaksanaan terhadap 28 (dua puluh delapan) material di lokasi proyek. Berdasarkan dari teknik yang dianalisa, teknik lotsizing yang menghasilkan biaya total paling ekonomis untuk semua material adalah teknik Periodic Order Quantity (POQ) dengan biaya sebesar Rp. 9.850.848.30, Sedangkan yang mempunyai biaya pengadaan material sangat tinggi ditunjukkan oleh teknik EOQ, Rp. 9.852.102.40, artinya biaya yang dikeluarkan lebih kecil yaitu Rp. $1.234 .00(97 \%)$.
\end{abstract}

Kata Kunci: Gedung Universitas Syiah Kuala, Material Requirement Planning, Lotsizing, Period Order Quantity, Economic Order Quantity

\begin{abstract}
One of the factors influencing the continuity running of a construction project is material procurement to the site. The delay in the arrival of construction materials which causes a stockout of material supplies when they will be used makes the work delayed. This can indirectly affect the total implementation time and project costs. by using the Material Requirement Planning method. The purpose of this study was to determine the order size and the most efficient material procurement costs from the two lotsizing inventory control techniques, namely the Period Order Quantity (POQ) and the Economic Order Quantity (EOQ) at Disaster Laboratory Building University of Syiah Kuala in Banda Aceh city. The processes contained in MRP is netting, lotting, offsetting, and explosion. The MRP method is applied to the Disaster Laboratory
\end{abstract}


Building University of Syiah Kuala project, by calculating the amount of material needed based on the Budget Plan data, Unit Price Analysis, and the project schedule which includes its 28 materials. Based on the analyzed technique, the lotsizing technique that produces the most economical total cost for all materials is the Periodic Order Quantity (POQ) technique with a cost of Rp. 9,850,848.30, while those who have very high material procurement costs are indicated by the EOQ technique, Rp. 9,852.102.40, meaning that the costs incurred are smaller, namely Rp. 1.234.00 (97\%).

Keywords: Building University of Syiah Kuala, Material Requirement Planning, Lotsizing, Period Order Quantity, Economic Order Quantity

\section{Latar Belakang}

Pada suatu proyek konstruksi, pengadaan material merupakan salah satu modal kerja yang cukup penting sebab sebagian besar sumber daya material digunakan dalam pelaksanaan pekerjaan, penggunaan material akan efisien dan efektif apabila tersedianya material pada saat dibutuhkan. Dalam pelaksanaan proyek, penggunaan material harus sesuai dengan spesifikasi dan kebutuhan yang telah ditetapkan (Limbong et al., 2013).

Proses dalam manajemen material antara lain pemilihan bahan, pemilihan pemasok barang, pembelian bahan, pengiriman bahan, penerimaan bahan, penyimpanan bahan, dan pengeluaran bahan (Siswanto \& Dewi, 2018). Salah satu metode perencanaan yang dapat digunakan dalam merencanakan kebutuhan material pada suatu proyek yaitu Material Requirement Planning (MRP) suatu metode perencanaan untuk menentukan material-material apa yang harus dibeli, kuantitas yang dibutuhkan, dan waktu material-material tersebut dibutuhkan. Metode MRP adalah teknik menentukan kuantitas dan waktu pembelian item permintaan dependent yang diperlukan untuk memenuhi kebutuhan jadwal material (Mariana, 2017). Metode MRP merupakan sebuah teknik permintaan dependent yang menggunakan daftar kebutuhan bahan, persediaan, penerimaan yang diperkirakan, dan jadwal material induk untuk menentukan kebutuhan material (Suudi \& others, 2021).

Proyek konstruksi Gedung Laboratorium Kebencanaan Universitas Syiah Kuala (USK) merupakan proyek konstruksi berskala besar yang tentunya menggunakan berbagai jenis bahan material dengan jumlah yang besar. Penelitian ini melibatkan manajemen konstruksi dengan mengaplikasikan metode MRP atau disebut dengan teknik lotsizing diantaranya teknik Economic Order Quantity (EOQ), teknik Period Order Quantity (POQ) yang dapat menghasilkan jumlah pesanan yang optimal dan memberikan total biaya persediaan minimum.

Dengan mengacu pada perumusan masalah maka tujuan yang ingin dicapai ialah menentukan jumlah kebutuhan material sebelum proses MRP pada pekerjaan serta mengetahui terbentuknya sistem penjadwalan pengadaan material yang optimal dengan metode MRP.

\section{Metode Penelitian}

Manajemen material didefinisikan sebagai suatu sistem manajemen yang diperlukan untuk merencanakan dan mengendalikan mutu material, jumlah material dan penempatan peralatan yang tepat waktu, harga yang baik dan jumlah yang sesuai dengan kebutuhan. Adapun proses dalam manajemen material antara lain pemilihan bahan, pemilihan pemasok barang, pembelian bahan, pengiriman bahan, 
penerimaan bahan, penyimpanan bahan, dan pengeluaran bahan (Iqbal et al., 2017), sedangkan jenis model utama dalam manajemen persediaan, yaitu model untuk persediaan independent dan model persediaan dependent (Imam, 2009).

Model persediaan independent adalah model penentuan jumlah pembelian material yang bersifat bebas, biasanya diaplikasikan untuk pembelian persediaan di mana permintaannya bersifat kontinyu dari waktu ke waktu dan bersifat konstanyaitu Economic Order Quantity (EOQ), Jumlah pesanan periode atau Period Order Quantity (POQ). Model persediaan dependent adalah model penentuan jumlah pembelian atau penyediaan material yang sangat tergantung kepada jumlah material akhir yang harus dibuat dalam suatu periode material tertentu. Model penentuan jumlah pembelian atau penyediaan dapat didekati dengan Material Requirement Planning (MRP).

Salah satu fungsi manajemen material yang sangat penting adalah pengendaliaan persediaan. Apabila suatu perusahaan menanamkan terlalu banyak dana pada persediaan, hal tersebut akan menyebabkan biaya penyimpanan yang berlebihan (Imam, 2009). Material Requirement Planning adalah suatu konsep dalam manajemen material yang membahas cara yang tepat dalam perencanaan kebutuhan barang dalam proses material (Astana \& Nyoman, 2007). Dalam hubungan ini terdapat 3 (Tiga) faktor penting, yaitu masukkan (input), keluaran (output), dan proses (Suudi \& others, 2021). MRP adalah sistem pengendalian dan perencanaan persediaan yang bergantung pada permintaan yang menjadwalkan jumlah yang tepat dari semua material yang dibutuhkan untuk mendukung produk akhir yang diinginkan (Dipohusodo, 1995).

Jumlah pesanan ekonomi atau Economic Order Quantity (EOQ) merupakan jumlah atau volume pembelian yang paling ekonomis untuk satu kali pembelian. Untuk mendapatkan nilai EOQ ada suatu rumus pendekatan yang dapat digunakan untuk melakukan perhitungan (Indrajit \& Djokopranoto, 2002) yaitu:

$$
Q^{*}=\sqrt{\frac{2 A \cdot D}{C}}
$$

di mana;

$$
\begin{aligned}
& \mathrm{Q}^{*} \text { : Jumlah pemesanan ekonomis tiap pesan (Economic Order Quantity) } \\
& \text { D : Jumlah kebutuhan rata-rata dalam satu periode (requirement) } \\
& \text { A : Biaya pemesanan tiap pesan (ordering cost) } \\
& \text { C : Biaya penyimpanan tiap satuan barang (carrying cost) }
\end{aligned}
$$

Jumlah pesanan periode atau Period Order Quantity (POQ) suatu pesanan dengan interval ekonomi dihitung menggunakan rata-rata tingkat biaya permintaan dan dibulatkan kepada bilangan bulat yang paling dekat atau lebih besar dari nol. Kuantitas masing-masing pesanan diproyeksikan pada kebutuhan yang diperlukan (Rosita et al., 2018), Persamaan sebagai berikut:

$$
E O I=\frac{E O Q}{R}=\sqrt{\frac{2 x C}{R P H}} .
$$

Keterangan:

EOI : Interval pesanan ekonomi di dalam suatu periode

C : Biaya pemesananan dalam setiap pemesanan

$\mathrm{H}$ : Persentase biaya simpan per periode

$\mathrm{P}$ : Harga pembelian per unit

R : Rata-rata permintaan pada setiap periode 
Gambaran umum mengenai pelaksanaan Proyek Konstruksi Gedung Laboratorium Kebencanaan Universitas Syiah Kuala ini dapat dijelaskan sebagai berikut:
1. Nama Proyek
: Pembangunan Gedung Laboratorium Kebencanaan Universitas Syiah Kuala
2. Jenis Proyek
3. Lokasi Proyek
: Pembangunan Gedung Laboratorium
: Gampong Kopelma Darussalam
Kecamatan Syiah Kuala - Kota Banda Aceh
2. Pemilik Proyek
: PPK Universitas Syiah Kuala
3. Kontraktor Pelaksana : PT. Perdana Dinamika Persada
4. Konsultan Perencana : PT. Kimcipta Persada Sejahtera
5. Konsultas Pengawas : CV. Ceudah Consultant
6. Masa Pelaksanaan : 283 hari kelender

Data kuantitatif berupa data yang bersifat angka atau bilangan, dalam penelitian ini data kuantitatif yang digunakan meliputi: data material, Bill of Material, lead time, data persediaan, dan biaya-biaya persediaan. Sedangkan, data kualitatif merupakan data informasi yang berbentuk kalimat verbal bukan berupa angka atau bilangan. Data sekunder adalah data pendukung yang diambil dari kontraktor pelaksana konstruksi, data tersebut berupa:

1. Jadwal Pelaksanaan Proyek, perlu direncanakan waktu dan jumlah tenaga yang dibutuhkan untuk menyelesaikan proyek tersebut. Dalam suatu perencanaan waktu dan penggunaan jumlah tenaga kerja diperlukan analisis harga satuan sebagai pedoman dalam perencanaan tersebut

2. Rencana Anggaran Biaya (RAB), dalam tahap perencanaan, penentuan RAB yang akan dikeluarkan untuk penyelesaian proyek. Satuan terkecil dari rencana anggaran biaya adalah harga satuan pekerjaan dimana harga satuan tersebut didapatkan dari perkalian antara koefisien tenaga kerja, bahan, dan alat dengan upah tenaga kerja atau harga bahan dan alat.

3. Analisa harga satuan pekerjaan adalah salah satu faktor penting dalam menentukan biaya proyek, setelah kuantitas pekerjaan. Dalam proses menghitung biaya proyek, maka kuantitas pekerjaan yang telah selesai dihitung akan ditransfer ke dalam nilai uang melalui harga satuan.

Adapun langkah-langkah mendasar pada proses pengolahan metode MRP menurut adalah sebagai berikut:

1. Eksplosion (perhitungan kebutuhan kotor) merupakan proses perhitungan kebutuhan kotor untuk tingkat item / komponen yang lebih bawah.

2. Netting (perhitungan kebutuhan bersih) adalah proses perhitungan untuk menetapkan jumlah kebutuhan bersih yang dasarnya merupakan selisih antara kebutuhan kotor dengan keadaan persediaan (yang ada dalam persediaan dan yang sedang dipesan). Masukan yang diperlukan dalam proses perhitungan kebutuhan bersih ini adalah: Kebutuhan kotor (Gross Requirement), yang merupakan jumlah kebutuhan yang akan dikonsumsi untuk tiap periode selama periode perencanaan.

3. Lotting (penentuan ukuran lot) adalah proses perhitungan besarnya pesanan optimum suatu bahan berdasarkan kebutuhan bersih hasil perhitungan netting. Proses lotting erat hubungannya dengan penentuan jumlah bahan yang harus 
dipesan atau disediakan. Proses lotting sendiri amat penting dalam rencana kebutuhan bahan, sehingga penggunaan dan pemilihan teknik yang tepat sangat mempengaruhi keefektifan rencana kebutuhan bahan.

4. Offsetting (penetapan besarnya lead time) bertujuan untuk menentukan saat yangtepat untuk melakukan rencana pemesanan dalam rangka memenuhi kebutuhan bersih dengan cara mengurangkan saat awal tersedianya ukuran lot yang diinginkan dengan besarnya lead time. Data yang telah diperoleh akan dianalisis dengan menggunakan beberapa metode MRP. Proses menentukan jumlah pesanan tiap komponen yang didasarkan kebutuhan bersih yang dihasilkan dari proses netting. Lotting yaitu

a. Jumlah pesanan ekonomi atau Economic Order Quantity (EOQ)

b. Jumlah pesanan periode atau Periodic Order Quantity (POQ).

\section{Hasil dan Pembahasan}

\subsection{Hasil}

\subsubsection{Gambaran Proyek}

Salah satu proyek pembangunan gedung yang sedang berjalan saat ini adalah Gedung Laboratorium Kebencanaan Universitas Syiah Kuala (USK) di Kota Banda Aceh. Gedung ini mulai di bangun sejak 16 Desember 2019 dan direncanakan selesai pada tahun 2020. Konstruksinya terdari 3 (tiga) lantai. Material yang Dikendalikan:

a. Semen: Persediaan dan penggunaan semen permintaan semen dilakukan dengan beberapa cara antara lain dikirim langsung ke lapangan yaitu semen untuk adukan ready mix (beton read-mix) untuk acian kolom dan sloof.

b. Pasir: Pasir yang digunakan dengan kriteria sisa di atas ayakan $4 \mathrm{~mm}$ harus minimum $2 \%$ berat, di atas ayakan $1 \mathrm{~mm}$ harus minimum $10 \%$ berat dan sisa di atas ayakan $0.25 \mathrm{~mm}$ harus berkisar antara $80 \%$ sampai $90 \%$ dari berat. Untuk pasokan pasir setiap harinya untuk pengadaan material finishing dalam kondisi slow down. Persediaan pasir tersebut disimpan langsung dalam gudang.

c. Besi: Pasokan besi dengan harga Rp. 13.000.00/Batang untuk besi beton polos, sedangkan Rp. 14.500.00/Batang untuk besi beton ulir. Besi tulangan yang digunakan adalah besi dengan ukuran besi D14, besi D16, besi $\varnothing 8$, besi $\varnothing 10$, besi $\emptyset 12$

\subsubsection{Struktur Material (Bill of Materials)}

Bill of Material adaiah suatu laporan yang berisi tentang keterangan mengenai semua bahan material yang dibutuhkan untuk menyelesaikan pekerjaan tersebut. Struktur produk ini memiliki empat tingkat peninjauan yaitu level $0,1,2$ dan 3 . Produk yang berada pada level 0 yaitu struktur lantai 1, 2, dan 3 merupakan produk akhir dari struktur ini, sedangkan produk yang berada di bawahnya merupakan komponen penyusunnya. Pengadaan material yang akan direncanakan adalah material penyusun pekerjaan bekisting, pembesian dan pengecoran. Dalam hal ini material yang akan diperhitungkan adalah material-material utama seperti semen, pasir dan besi tulangan.

\subsubsection{Perencanaan Biaya Material}

Biaya persediaan adalah semua pengeluaran dan kerugian yang timbul sebagai akibat dari adanya persediaan material. Biaya pembelian material adalah 
biaya yang dikeluarkan untuk membeli material. Sebagaimana yang terlihat pada Tabel 1.

Tabel 1. Data harga material

\begin{tabular}{lccccccc}
\hline No & Material & unit & Harga (Rp) & No & Material & unit & Harga (Rp) \\
\hline 1 & Plywood Tebal 9 mm & Lembar & $210,000.00$ & 15 & Beton K-125 & $\mathrm{m}^{3}$ & $850,000.00$ \\
\hline 2 & Kayu Kelas III & $\mathrm{m}^{3}$ & $3,300,000$. & 16 & Beton K-175 & $\mathrm{m}^{3}$ & $910,000.00$ \\
\hline 3 & Balok Kayu Kelas II & $\mathrm{m}^{3}$ & $4,800,000$. & 17 & Beton K-200 & $\mathrm{m}^{3}$ & $940,000.00$ \\
\hline 4 & Dolken Kayu Ø 8-10cm/4m & Batang & $13,000.00$ & 18 & Beton K-250 & $\mathrm{m}^{3}$ & $995,000.00$ \\
\hline 5 & Besi Ø 8 & Batang & $41,000.00$ & 19 & Beton K-300 & $\mathrm{m}^{3}$ & $1,085,000.00$ \\
\hline 6 & Besi Ø 10 & Batang & $61,000.00$ & 20 & Bata Merah & Buah & 650.00 \\
\hline 7 & Besi Ø 12 & Batang & $89,000.00$ & 21 & $\begin{array}{c}\text { Granit Polished Uk. 60x60 cm } \\
\text { @ 3 pcs }\end{array}$ & Kotak & $380,000.00$ \\
\hline 8 & Besi D 13 & Batang & $136,000.00$ & 22 & Granit Uk. 10x60 cm @ 18 pcs & Kotak & $432,000.00$ \\
\hline 9 & Besi D 14 & Batang & $160,000.00$ & 23 & $\begin{array}{c}\text { Keramik Uk. 30 x 30 cm Ex. } \\
\text { Roman @ 11 pcs }\end{array}$ & Kotak & $180,000.00$ \\
\hline 10 & Besi D 16 & Batang & $208,000.00$ & 24 & $\begin{array}{c}\text { Keramik Uk. 30 x 60 cm Ex. } \\
\text { Roman @ 6 pcs }\end{array}$ & Kotak & $210,000.00$ \\
\hline 11 & Besi D 19 & Batang & $295,000.00$ & 25 & Pasir Pasang & $\mathrm{m}^{3}$ & $160,000.00$ \\
\hline 12 & Besi D 22 & Batang & $305,000.00$ & 26 & Semen Portland @ 40 kg & Zak & $55,000.00$ \\
\hline 13 & Wiremesh M10 & Lembar & $730,000.00$ & 27 & Semen Warna @ 1 kg & Zak & $20,000.00$ \\
\hline 14 & Baut Angkur Ø 1" & Buah & $150,000.00$ & 28 & $\begin{array}{c}\text { Keramik Uk. 30 x 60 cm Ex. } \\
\text { Kotak }\end{array}$ & $210,000.00$ \\
\hline
\end{tabular}

Biaya pemesanan adalah semua biaya pengeluaran yang timbul dari usaha untuk mendatangkan material dari luar proyek. Biaya pemesanan pada proyek ini meliputi biaya telekomunikasi dan biaya administrasi meliputi biaya telekomunikasi, Seperti Pada Tabel 2.

Tabel 2. Biaya pemesanan

\begin{tabular}{clccccc}
\hline No & \multicolumn{1}{c}{ Uraian Biaya } & Lokasi Pesan & Volume & Satuan & $\begin{array}{c}\text { Harga } \\
\text { Satuan (Rp) }\end{array}$ & $\begin{array}{c}\text { Jumlah } \\
\text { Harga (Rp) }\end{array}$ \\
\hline 1 & $\begin{array}{l}\text { Biaya Telepon (biaya untuk } \\
\text { melakukan pemesanan material) }\end{array}$ & $\begin{array}{c}\text { Banda Aceh } \\
- \text { Aceh Besar }\end{array}$ & 10 & Menit & 102.00 & 1.022 .22 \\
\hline 2 & $\begin{array}{l}\text { Biaya dokumen teks (Biaya } \\
\text { Pengiriman list material) }\end{array}$ & $\begin{array}{c}\text { Banda Aceh } \\
- \text { Aceh Besar }\end{array}$ & 3 & Lembar & 1.770 .00 & 5.310 .00 \\
\hline 3 & $\begin{array}{l}\text { Biaya admin (Biaya pencatatan } \\
\text { dan pendataan material) }\end{array}$ & $\begin{array}{c}\text { Banda Aceh } \\
- \text { Aceh Besar }\end{array}$ & 3 & Lembar & 500.00 & 1.500 .00 \\
\hline Total Keseluruhan & & & & 7.832 .00 \\
\hline
\end{tabular}

Biaya penyimpanan yang diperhitungkan berupa biaya karena memiliki persediaan (inventory) dan biaya kerusakan atau penyusutan. Biaya persediaan (inventory) dapat diukur dengan suku bunga bank sebesar $4.25 \%$ per tahun (berdasarkan suku bunga BI 2020 dan Maret 2021). Adapun perhitungan biaya penyimpanan material per hari adalah sebagai berikut:

Material Besi : $\frac{(\text { Suku Bunga }+ \text { Angka Penyusutan) }}{\text { Periode (Hari) }} x$ Harga Material Per Unit

Material Besi : $\frac{(4,25 \%+0,5 \%)}{365 \text { hari }} \times$ Harga Material Per Unit

\subsubsection{Perhitungan Metode Lotsizing}

Analisa perhitungan jumlah pesanan material optimum ini meliputi perhitungan penentuan ukuran lot (lotzising) dan waktu rencana pemesanan (offseting). Proses lotting bertujuan untuk menentukan besarnya jumlah pesanan 
yang optimal berdasarkan hasil dari perhitungan kebutuhan material per periode. Proses offsetting bertujuan untuk menentukan waktu rencana pemesanan guna dapat dilihat Pada Tabel 3.

Tabel. 3. Perhitungan output metode lotsizing

\begin{tabular}{|c|c|c|c|c|c|c|}
\hline \multirow{2}{*}{ Item } & \multirow{2}{*}{ Satuan } & & \multicolumn{2}{|c|}{$\begin{array}{c}\text { Teknik Economic Order } \\
\text { Quantity (EOQ }\end{array}$} & \multicolumn{2}{|c|}{$\begin{array}{c}\text { Teknik Period Order } \\
\text { Quantity (POQ). }\end{array}$} \\
\hline & & & Total & $\begin{array}{l}\text { Frekuensi } \\
\text { Pemesanan }\end{array}$ & Total & $\begin{array}{l}\text { Frekuensi } \\
\text { Pemesanan }\end{array}$ \\
\hline \multirow{4}{*}{$\begin{array}{l}\text { Plywood } \\
\text { Tebal } 9 \mathrm{~mm}\end{array}$} & \multirow{4}{*}{ Lembar } & Kebutuhan Bersih & $1,895.00$ & \multirow{4}{*}{21} & $1,895.00$ & \multirow{4}{*}{21} \\
\hline & & Persediaan di gudang & $4,771.00$ & & $4,198.00$ & \\
\hline & & Jumlah Pesanan (isi kembali) & $1,895.00$ & & $1,895.00$ & \\
\hline & & Jumlah Pesanan (dikeluarkan) & $1,895.00$ & & $1,895.00$ & \\
\hline \multirow{4}{*}{$\begin{array}{l}\text { Kayu Kelas } \\
\text { III }\end{array}$} & \multirow{4}{*}{ M3 } & Kebutuhan Bersih & 269.00 & \multirow{4}{*}{8} & 269.00 & \multirow{4}{*}{9} \\
\hline & & Persediaan di gudang & $2,747.00$ & & $2,358.00$ & \\
\hline & & Jumlah Pesanan (isi kembali) & 269.00 & & 269.00 & \\
\hline & & Jumlah Pesanan (dikeluarkan) & 269.00 & & 269.00 & \\
\hline \multirow{4}{*}{$\begin{array}{l}\text { Balok Kayu } \\
\text { Kelas II }\end{array}$} & \multirow{4}{*}{ M3 } & Kebutuhan Bersih & 86.00 & \multirow{4}{*}{5} & 86.00 & \multirow{4}{*}{6} \\
\hline & & Persediaan di gudang & $1,403.00$ & & $1,115.00$ & \\
\hline & & Jumlah Pesanan (isi kembali) & 86.00 & & 86.00 & \\
\hline & & Jumlah Pesanan (dikeluarkan) & 86.00 & & 86.00 & \\
\hline \multirow{4}{*}{$\begin{array}{l}\text { Dolken } \\
\text { Kayu } \varnothing 8-10 \\
\text { cm/4m }\end{array}$} & \multirow{4}{*}{ Batang } & Kebutuhan Bersih & $22,505.00$ & \multirow{4}{*}{4} & $22,505.00$ & \multirow{4}{*}{7} \\
\hline & & Persediaan di gudang & $392,070.00$ & & $239,042.00$ & \\
\hline & & Jumlah Pesanan (isi kembali) & $22,505.00$ & & $22,505.00$ & \\
\hline & & Jumlah Pesanan (dikeluarkan) & $22,505.00$ & & $22,505.00$ & \\
\hline \multirow{4}{*}{ Besi $\varnothing 8$} & \multirow{4}{*}{ Batang } & Kebutuhan Bersih & 347.00 & & 347.00 & \\
\hline & & Persediaan di gudang & $10,589.00$ & 2 & 624.00 & 4 \\
\hline & & Jumlah Pesanan (isi kembali) & 347.00 & & 347.00 & \\
\hline & & Jumlah Pesanan (dikeluarkan) & 347.00 & & 347.00 & \\
\hline & & Kebutuhan Bersih & $17,494.00$ & & $17,494.00$ & \\
\hline & & Persediaan di gudang & $37,290.00$ & 32 & $28,004.00$ & 31 \\
\hline Bes1 Ø 10 & Batang & Jumlah Pesanan (isi kembali) & $17,494.00$ & & $17,494.00$ & \\
\hline & & Jumlah Pesanan (dikeluarkan) & $17,494.00$ & & $17,494.00$ & \\
\hline & & Kebutuhan Bersih & 790.00 & & 790.00 & \\
\hline & & Persediaan di gudang & $16,485.00$ & & $1,006.00$ & 10 \\
\hline Bes1 Ø 12 & Batang & Jumlah Pesanan (isi kembali) & 790.00 & 4 & 790.00 & \\
\hline & & Jumlah Pesanan (dikeluarkan) & 790.00 & & 790.00 & \\
\hline & & $\underline{\text { Kebutuhan Bersih }}$ & $3,487.00$ & & $3,487.00$ & \\
\hline & & Persediaan di gudang & $11,254.00$ & & $5,566.00$ & \\
\hline Bes1 D 13 & Batang & Jumlah Pesanan (isi kembali) & $3,487.00$ & 14 & $3,487.00$ & 16 \\
\hline & & Jumlah Pesanan (dikeluarkan) & $3,487.00$ & & $3,487.00$ & \\
\hline & & Kebutuhan Bersih & $5,053.00$ & & $5,053.00$ & \\
\hline & & Persediaan di gudang & $7,821.00$ & & $5,165.00$ & 15 \\
\hline Bes1 D 14 & Batang & Jumlah Pesanan (isi kembali) & $5,053.00$ & 17 & $5,053.00$ & \\
\hline & & Jumlah Pesanan (dikeluarkan) & $5,053.00$ & & $5,053.00$ & \\
\hline & & Kebutuhan Bersih & $1,410.00$ & & $1,410.00$ & \\
\hline & & Persediaan di gudang & $7,758.00$ & & $2,105.00$ & 15 \\
\hline Bes1 D 16 & Batang & Jumlah Pesanan (isi kembali) & $1,410.00$ & 11 & $1,410.00$ & \\
\hline & & Jumlah Pesanan (dikeluarkan) & $1,410.00$ & & $1,410.00$ & \\
\hline & & Kebutuhan Bersih & 569.00 & & 569.00 & \\
\hline Besi D 10 & Batano & Persediaan di gudang & $4,338.00$ & 5 & $1,200.00$ & 5 \\
\hline Bes1 D 19 & Batang & Jumlah Pesanan (isi kembali) & 569.00 & 5 & 569.00 & \\
\hline & & Jumlah Pesanan (dikeluarkan) & 569.00 & & 569.00 & \\
\hline & & Kebutuhan Bersih & $2,314.00$ & 20 & $2,314.00$ & 25 \\
\hline Bes1 D 22 & Batang & Persediaan di gudang & $6,334.00$ & 20 & $2,860.00$ & \\
\hline
\end{tabular}




\begin{tabular}{|c|c|c|c|c|c|c|}
\hline & & Jumlah Pesanan (isi kembali) & $2,314.00$ & & $2,314.00$ & \\
\hline & & Jumlah Pesanan (dikeluarkan) & $2,314.00$ & & $2,314.00$ & \\
\hline \multirow{4}{*}{$\begin{array}{l}\text { Wiremesh } \\
\text { M10 }\end{array}$} & \multirow{4}{*}{ Lembar } & Kebutuhan Bersih & 12.00 & \multirow{4}{*}{1} & 12.00 & \multirow{4}{*}{1} \\
\hline & & Persediaan di gudang & 18.00 & & 18.00 & \\
\hline & & Jumlah Pesanan (isi kembali) & 12.00 & & 12.00 & \\
\hline & & Jumlah Pesanan (dikeluarkan) & 12.00 & & 12.00 & \\
\hline \multirow{4}{*}{$\begin{array}{l}\text { Baut } \\
\text { Angkur } \varnothing \\
1 "\end{array}$} & \multirow{4}{*}{ Buah } & Kebutuhan Bersih & 12.00 & \multirow{4}{*}{1} & 12.00 & \multirow{4}{*}{1} \\
\hline & & Persediaan di gudang & 0.00 & & 0.00 & \\
\hline & & Jumlah Pesanan (isi kembali) & 12.00 & & 12.00 & \\
\hline & & Jumlah Pesanan (dikeluarkan) & 12.00 & & 12.00 & \\
\hline \multirow{4}{*}{$\begin{array}{l}\text { Beton K- } \\
125\end{array}$} & \multirow{4}{*}{ M3 } & Kebutuhan Bersih & 198.00 & \multirow{4}{*}{20} & 198.00 & \multirow{4}{*}{20} \\
\hline & & Persediaan di gudang & 0.00 & & 0.00 & \\
\hline & & Jumlah Pesanan (isi kembali) & 198.00 & & 198.00 & \\
\hline & & Jumlah Pesanan (dikeluarkan) & 198.00 & & 198.00 & \\
\hline \multirow{4}{*}{$\begin{array}{l}\text { Beton K- } \\
175\end{array}$} & \multirow{4}{*}{ M3 } & Kebutuhan Bersih & 25.00 & \multirow{4}{*}{7} & 25.00 & \multirow{4}{*}{7} \\
\hline & & Persediaan di gudang & 0.00 & & 0.00 & \\
\hline & & Jumlah Pesanan (isi kembali) & 25.00 & & 25.00 & \\
\hline & & Jumlah Pesanan (dikeluarkan) & 25.00 & & 25.00 & \\
\hline \multirow{4}{*}{$\begin{array}{l}\text { Beton K- } \\
200\end{array}$} & \multirow{4}{*}{ M3 } & Kebutuhan Bersih & 4.00 & \multirow{4}{*}{6} & 4.00 & \\
\hline & & Persediaan di gudang & 0.00 & & 0.00 & 6 \\
\hline & & Jumlah Pesanan (isi kembali) & 4.00 & & 4.00 & \\
\hline & & Jumlah Pesanan (dikeluarkan) & 4.00 & & 4.00 & \\
\hline & & Kebutuhan Bersih & 23.00 & & 23.00 & \\
\hline Beton K- & M3 & Persediaan di gudang & 0.00 & 6 & 0.00 & 6 \\
\hline 250 & 1013 & Jumlah Pesanan (isi kembali) & 23.00 & & 23.00 & \\
\hline & & Jumlah Pesanan (dikeluarkan) & 23.00 & & 23.00 & \\
\hline & & Kebutuhan Bersih & $2,191.00$ & & $2,191.00$ & \\
\hline Beton K- & & Persediaan di gudang & 0.00 & 44 & 0.00 & 44 \\
\hline 300 & & Jumlah Pesanan (isi kembali) & $2,191.00$ & & $2,191.00$ & \\
\hline & & Jumlah Pesanan (dikeluarkan) & $2,191.00$ & & $2,191.00$ & \\
\hline & & Kebutuhan Bersih & $234,051.00$ & & $234,051.00$ & \\
\hline & Buah & Persediaan di gudang & $591,530.00$ & 9 & $443,223.00$ & 11 \\
\hline Merah & Buah & Jumlah Pesanan (isi kembali) & $234,051.00$ & & $234,051.00$ & \\
\hline & & Jumlah Pesanan (dikeluarkan) & $234,051.00$ & & $234,051.00$ & \\
\hline Granit & & Kebutuhan Bersih & $2,706.00$ & & $2,706.00$ & \\
\hline Polished & & Persediaan di gudang & $5,832.00$ & 23 & $2,458.00$ & 25 \\
\hline Uk. $60 \times 60$ & Kotak & Jumlah Pesanan (isi kembali) & $2,706.00$ & & $2,706.00$ & \\
\hline $\mathrm{cm}$ & & Jumlah Pesanan (dikeluarkan) & $2,706.00$ & & $2,706.00$ & \\
\hline & & Kebutuhan Bersih & 42.00 & & 42.00 & \\
\hline Granit Uk & & Persediaan di gudang & 212.00 & 2 & 103.00 & 2 \\
\hline $10 \times 60 \mathrm{~cm}$ & Kotak & Jumlah Pesanan (isi kembali) & 42.00 & & 42.00 & \\
\hline & & Jumlah Pesanan (dikeluarkan) & 42.00 & & 42.00 & \\
\hline & & Kebutuhan Bersih & 43.00 & & 43.00 & \\
\hline $\begin{array}{l}\text { Keramik } \\
\text { Ju } 30 \times 30\end{array}$ & Kotak & Persediaan di gudang & $2,236.00$ & 1 & 45.00 & 3 \\
\hline $\mathrm{cm} 30 \times 30$ & Котак & Jumlah Pesanan (isi kembali) & 43.00 & & 43.00 & \\
\hline & & Jumlah Pesanan (dikeluarkan) & 43.00 & & 43.00 & \\
\hline & & Kebutuhan Bersih & 157.00 & & 157.00 & \\
\hline $\begin{array}{l}\text { Keramik } \\
\text { Uk } 30 \times 60\end{array}$ & Kotak & Persediaan di gudang & $2,160.00$ & 3 & 452.00 & 3 \\
\hline UK $30 \times 60$ & Kотак & Jumlah Pesanan (isi kembali) & 157.00 & & 157.00 & \\
\hline & & Jumlah Pesanan (dikeluarkan) & 157.00 & & 157.00 & \\
\hline & & Kebutuhan Bersih & 490.00 & & 490.00 & \\
\hline Pasir & $M 3$ & Persediaan di gudang & $3,146.00$ & 10 & $2,478.00$ & 10 \\
\hline Pasang & M3 & Jumlah Pesanan (isi kembali) & 490.00 & & 490.00 & \\
\hline & & Jumlah Pesanan (dikeluarkan) & 490.00 & & 490.00 & \\
\hline
\end{tabular}




\begin{tabular}{|c|c|c|c|c|c|c|}
\hline \multirow{4}{*}{ Pasir Urug } & \multirow{4}{*}{ M3 } & Kebutuhan Bersih & 176.00 & \multirow{4}{*}{2} & 176.00 & \multirow{4}{*}{8} \\
\hline & & Persediaan di gudang & $3,685.00$ & & 624.00 & \\
\hline & & Jumlah Pesanan (isi kembali) & 176.00 & & 176.00 & \\
\hline & & Jumlah Pesanan (dikeluarkan) & 176.00 & & 176.00 & \\
\hline \multirow{4}{*}{$\begin{array}{l}\text { Semen } \\
\text { Portland }\end{array}$} & \multirow{4}{*}{ Zak } & Kebutuhan Bersih & $3,924.00$ & \multirow{4}{*}{16} & $3,924.00$ & \multirow{4}{*}{17} \\
\hline & & Persediaan di gudang & $19,280.00$ & & $11,569.00$ & \\
\hline & & Jumlah Pesanan (isi kembali) & $3,924.00$ & & $3,924.00$ & \\
\hline & & Jumlah Pesanan (dikeluarkan) & $3,924.00$ & & $3,924.00$ & \\
\hline \multirow{4}{*}{$\begin{array}{l}\text { Semen } \\
\text { Warna }\end{array}$} & \multirow{4}{*}{ Zak } & Kebutuhan Bersih & $4,351.00$ & \multirow{4}{*}{8} & $4,351.00$ & \multirow{4}{*}{10} \\
\hline & & Persediaan di gudang & $33,488.00$ & & $15,005.00$ & \\
\hline & & Jumlah Pesanan (isi kembali) & $4,351.00$ & & $4,351.00$ & \\
\hline & & Jumlah Pesanan (dikeluarkan) & $4,351.00$ & & $4,351.00$ & \\
\hline
\end{tabular}

\subsubsection{Penggunaan Lot Sizing yang Paling Efektif}

Berdasarkan tabel - tabel tersebut dapat dilihat bahwa hampir semua metode memiliki total biaya yang sama, sedangkan teknik Economic Order Quantity dan memiliki total biaya yang lebih mahal dibandingkan teknik Fixed Order Quantity. Dapat dilihat pada Tabel 4.

Tabel 4. Rekapitulasi metode lotsizing

\begin{tabular}{|c|c|c|c|c|c|c|c|c|c|}
\hline \multirow[t]{2}{*}{ Item } & \multirow[t]{2}{*}{ Satuan } & \multicolumn{2}{|c|}{$\begin{array}{l}\text { Jumlah Total Biaya } \\
\text { Persediaan (Rp) }\end{array}$} & \multirow[t]{2}{*}{ Deviasi } & \multirow[t]{2}{*}{ Item } & \multirow[t]{2}{*}{ Satuan } & \multicolumn{2}{|c|}{$\begin{array}{l}\text { Jumlah Total Biaya } \\
\text { Persediaan (Rp) }\end{array}$} & \multirow[t]{2}{*}{ Deviasi } \\
\hline & & EOQ & FOQ & & & & EOQ & FOQ & \\
\hline $\begin{array}{l}\text { Plywood } \\
\text { Tebal } 9 \mathrm{~mm}\end{array}$ & Lembar & $398,286.1$ & $398,265.5$ & 14.566 & $\begin{array}{l}\text { Beton K- } \\
\quad 125\end{array}$ & $\mathrm{~m}^{3}$ & $168,456.7$ & $168,456.7$ & 0.0000 \\
\hline $\begin{array}{c}\text { Kayu Kelas } \\
\text { III }\end{array}$ & $\mathrm{m}^{3}$ & $890,515.0$ & $890,453.0$ & 43.841 & $\begin{array}{l}\text { Beton K- } \\
175\end{array}$ & $\mathrm{~m}^{3}$ & $22,804.90$ & $22,804.90$ & 0.000 \\
\hline $\begin{array}{c}\text { Balok Kayu } \\
\text { Kelas II }\end{array}$ & $\mathrm{m}^{3}$ & $414,742.4$ & $414,663.5$ & 55.791 & $\begin{array}{l}\text { Beton K- } \\
200\end{array}$ & $\mathrm{~m}^{3}$ & $3,807.00$ & $3,807.00$ & 0.000 \\
\hline $\begin{array}{c}\text { Dolken Kayu } \\
\varnothing 8-10 \mathrm{~cm} / \\
4 \mathrm{~m} \\
\end{array}$ & Batang & $294,070.8$ & $294,203.0$ & 93.480 & $\begin{array}{l}\text { Beton K- } \\
250\end{array}$ & $\mathrm{~m}^{3}$ & $22,932.00$ & $22,932.00$ & 0.000 \\
\hline Besi $\varnothing 8$ & Batang & $14,299.3$ & $14,261.8$ & 26.517 & $\begin{array}{l}\text { Beton K- } \\
300\end{array}$ & $\mathrm{~m}^{3}$ & $\begin{array}{c}2,377,579 . \\
70\end{array}$ & $\begin{array}{c}2,377,579 . \\
70\end{array}$ & 0.000 \\
\hline Besi $\varnothing 10$ & Batang & $\begin{array}{c}1,067,680 . \\
8\end{array}$ & $1,067,599.2$ & 57.700 & $\begin{array}{c}\text { Bata } \\
\text { Merah }\end{array}$ & Buah & $152,268.80$ & $\begin{array}{c}152,268.2 \\
0\end{array}$ & 0.424 \\
\hline Besi $\varnothing 12$ & Batang & $70,532.3$ & $70,400.1$ & 93.480 & $\begin{array}{c}\text { Granit } \\
\text { Polished Uk. } \\
\text { 60x60 cm @ } \\
3 \text { pcs }\end{array}$ & Kotak & $\begin{array}{c}1,028,839 \\
70\end{array}$ & $\begin{array}{c}1,028,635 \\
90\end{array}$ & 144.108 \\
\hline Besi D 13 & Batang & $474,540.9$ & $474,456.0$ & 60.033 & $\begin{array}{l}\text { Granit Uk. } \\
10 x 60 \mathrm{~cm} \\
@ 18 \mathrm{pcs}\end{array}$ & Kotak & $18,175.40$ & $18,167.40$ & 5.657 \\
\hline Besi D 14 & Batang & $808,776.1$ & $808,705.1$ & 50.205 & $\begin{array}{c}\text { Keramik } \\
\text { Uk. } 30 \mathrm{x} \\
30 \mathrm{~cm} \text { Ex. } \\
\text { Roman @ } \\
11 \text { pcs } \\
\end{array}$ & Kotak & $7,816.90$ & $7,764.90$ & 36.770 \\
\hline Besi D 16 & Batang & $293,576.3$ & $293,454.5$ & 86.126 & $\begin{array}{c}\text { Keramik } \\
\text { Uk. 30 x } \\
60 \mathrm{~cm} \text { Ex. } \\
\text { Roman @ } \\
6 \text { pcs } \\
\end{array}$ & Kotak & $33,071.20$ & $33,009.80$ & 43.416 \\
\hline Besi D 19 & Batang & $168,060.8$ & $167,940.3$ & 85.206 & $\begin{array}{c}\text { Pasir } \\
\text { Pasang }\end{array}$ & $\mathrm{m}^{3}$ & $78,564.70$ & $78,546.30$ & 13.011 \\
\hline
\end{tabular}




\begin{tabular}{|c|c|c|c|c|c|c|c|c|c|}
\hline Besi D 22 & Batang & $706,178.1$ & $706,079.5$ & 69.721 & $\begin{array}{c}\text { Semen } \\
\text { Portland } \\
\text { @ } 40 \mathrm{~kg} \\
\end{array}$ & Zak & $22,624.50$ & $22,604.40$ & 14.213 \\
\hline $\begin{array}{l}\text { Wiremesh } \\
\text { M10 }\end{array}$ & Lembar & $8,769.7$ & $8,769.7$ & 0.0000 & $\begin{array}{c}\text { Semen } \\
\text { Warna @ } \\
1 \mathrm{~kg} \\
\end{array}$ & Zak & $216,127.10$ & $\begin{array}{c}216,062.2 \\
0\end{array}$ & 45.891 \\
\hline $\begin{array}{c}\text { Baut Angkur } \\
\varnothing 1^{\prime \prime}\end{array}$ & Buah & $1,807.9$ & $1,807.9$ & 0.0000 & $\begin{array}{c}\text { Keramik } \\
\text { Uk. 30x } \\
60 \mathrm{~cm} \text { Ex. } \\
\text { Roman @ } \\
6 \text { pcs }\end{array}$ & Kotak & $87,197.30$ & $87,149.80$ & 33.588 \\
\hline
\end{tabular}

\subsection{Pembahasan}

Secara umum, Metode MRP memiliki kelebihan dan kekurangan. Adapun kelebihan MRP antara lain memberitahu kapan memperlambat akan sebaik mempercepat, menunda atau membatalkan pesanan, mengubah kuantitas pesanan, memajukan atau menunda batas waktu pesan, dan membantu perencanaan kapasitas. Sedangkan kekurangan MRP ialah jika terdapat data salah pada data persediaan, bill material/master schedule juga akan menghasilkan data salah. Kegagalan dalam mengaplikasikan MRP biasanya disebabkan oleh kurangnya komitmen pada manajemen material.

Dalam penelitian ini, cara menerapkan langkah-langkah dalam sistem MRP mulai dari proses kebutuhan kotor (ekplosion), kebutuhan bersih (netting), ukuran pemesanan (lotting), dan waktu pemesanan (offsenting).

Kebutuhan kotor merupakan jumlah setiap item yang dibutuhkan untuk dikonsumsi. Kebutuhan kotor untuk tiap komponen merupakan gabungan dari rencana periode dan jadwal induk produksi. Data yang diperlukan untuk menghitung kebutuhan kotor material per periode ini meliputi jadwal induk produksi dan kebutuhan material total.

Perhitungan kebutuhan bersih ini diperlukan untuk menetapkan jumlah kebutuhan bersih material. Jumlah kebutuhan bersih merupakan selisih antara kebutuhan kotor dengan persediaan yang dimiliki pada awal perencanaan, sehingga dapat diketahui untuk jumlah kebutuhan bersih dengan jumlah kebutuhan kotor.

Proses lotting bertujuan untuk menentukan besarnya jumlah pesanan yang optimal berdasarkan hasil dari perhitungan kebutuhan bersih. Proses lotting ini digunakan untuk level paling bawah yaitu material dari proses explosion. Teknik penentuan ukuran pesanan yang akan digunakan dalam penelitian ini antara lain teknik jumlah pesanan ekonomi atau Economic Order Quantity (EOQ) dan teknik jumlah pesanan periode atau Periodic Order Quantity (POQ). Dengan MRP menggunakan teknik pemesanan menghasilkan biaya persediaan EOQ Rp. 9.852.102.40 dan POQ Rp 9.850.848.30.

Pada proses akhir sistem MRP dalam penelitian ini yaitu offsetting, perusahaan akan dapat mengetahui kapan waktu yang tepat untuk melakukan pemesanan barang dengan membuat tabel MRP yang sesuai atau berdasarkan oleh lead time dan langkah sebelumnya (netting dan lotting). Proses offsetting bertujuan untuk menentukan waktu rencana pemesanan guna memenuhi kebutuhan bersih agar material dapat tersedia tepat waktu pada saat dibutuhkan. Waktu rencana pemesanan diperoleh dengan memperhitungkan besarnya leadtime pengadaan suatu material. 
Tabel MRP akan memberikan gambaran bagi perusahaan mengenai waktu pemesanan yang tepat untuk tiap material, sehingga tidak akan terjadi penghentian proses produksi karena keterlambatan barang atau kekurangan barang akan tetapi cenderung memilih untuk menggunakan teknik Fixed Order Quantity karena bertujuan mendapatkan solusi optimal untuk jumlah unit pemesanan selama waktu yang telah ditentukan.

\section{Kesimpulan dan Saran \\ 4.1 Kesimpulan}

Dari hasil penelitian maka dapat disimpulkan bahwa aplikasi sistem informasi persediaan barang ini menggunakan teknik Periodic Order Quantity (POQ) merupakan metode pemesanan material yang menghasilkan biaya pengadaan material yang paling rendah, karena hasil akhir total biaya persediaan untuk tiap material secara keseluruhan lebih kecil jika dibandingkan dengan menggunakan Teknik Economic Order Quantity (EOQ). Aplikasi sistem informasi pengadaan material pada proyek konstruksi gedung laboratorium kebencanaan Universitas Syiah Kuala (USK) dengan menerapkan metode Material Requirement Planning (MRP) lebih baik menggunakan metode Lot Sizing.

\subsection{Saran}

Dalam penerapan metode MRP pada suatu proyek yang harus diperhatikan adalah pemilihan teknik lot-sizing yang sesuai dengan keadaan proyek guna mendapatkan hasil yang memuaskan. Teknik lot-sizing Fixed Order Quantity didasarkan pada perhitungan yang realistis sehingga dapat meminimalisasi persediaan bahan maupun biaya persediaan dalam suatu proyek

\section{Ucapan Terimakasih}

Diucapkan terima kasih kepada semua pihak yang telah berkontribusi dalam penelitian ini, sehingga penelitian dapat terlaksana dengan baik

\section{Daftar Kepustakaan}

Astana, I. N. Y., \& Nyoman, I, 2007. Perencanaan persediaan bahan baku berdasarkan metode MRP (Material Requirements Planning). Jurnal Ilmiah Teknik Sipil, 11(2), 184-194.

Dipohusodo, Istimawan, 1995. Manajemen Proyek \& Konstruksi Jilid 1. Badan Penerbit Kanisius, Yogyakarta

Heizer, Jay \& Renderbarry, 2015. Manajemen Operasi: Manajemen keberlangsungan dan rantai pasokan, Edisi 11. Salemba empat, Jakarta

Imam, K, 2009. Manajemen Persediaan. Tidak Dipublikasikan. Buku Ajar. Jember: Fakultas Ekonomi Universitas Jember. 
Indrajit, R. E., \& Djokopranoto, R, 2002. The concept of Supply Chain Management: New Ways of Looking at Goods Supply Chain. PT. Gramedia Widiasarana Indonesia, Jakarta

Iqbal, T., Aprizal, D., \& Wali, M, 2017. Aplikasi Manajemen Persediaan Barang Berbasis Economic Order Quantity (EOQ). Jurnal JTIK (Jurnal Teknologi Informasi Dan Komunikasi), 1(1), 48-60.

Limbong, I., Tarore, H., Tjakra, J., \& Walangitan, D. R. O, 2013. Manajemen Pengadaan Material Bangunan dengan Menggunakan Metode MRP (Material Requirement Planning) Studi Kasus: Revitalisasi Gedung Kantor BPS Propinsi Sulawesi Utara. Jurnal Sipil Statik, 1(6).

Lolo, C. A, 2017. Perencanaan Persediaan Material Proyek Dengan Metode LotSizing. Jurusan Sipil, Fakultas Teknik Universitas Hasanuddin, Makassar.

Mariana, I, 2017. Penerapan Metode Material Requirement Planning (MRP) dalam Perencanaan Persediaan Bahan Baku Biji Plastik untuk Meminimumkan Biaya Persediaan pada PT UNISON JAYA di Tangerang. Business Management Journal, 4(2).

Rosita, R., Hufron, M., \& ABS, M. K, 2018. Penerapan Metode Just In Time (JIT) untuk Meningkatkan Efisiensi Persediaan Bahan Baku pada Home Industry "MULYA COLLECTION" JOMBANG. Jurnal Ilmiah Riset Manajemen, $7(02)$.

Siswanto, A. B., \& Dewi, K, 2018. Penerapan Manajemen Material pada Proyek Konstruksi di SUMBA (Studi Kasus di Kabupaten Sumba Tengah). Jurnal Teknik Sipil, 8.

Suudi, M. Y., \& others, 2021. Pengaruh Bahan Baku dan Manajemen Rantai Pasokan terhadap Proses Produksi PT. NIRO CERAMIC NASIONAL INDONESIA. Jurnal Ekonomi Dan Industri, 22(1). 